\title{
Urban attractiveness in public squares: the mutual influence of the urban environment and the social activities in Batna
}

\author{
Atratividade urbana em praças públicas: a influência mútua do ambiente \\ urbano e das atividades sociais em Batna
}

Wided Guedoudj[a) (D), Ahmed Ghenouchi[b], Jean-Yves Toussaint[c] (D)

\begin{abstract}
[a] University of Batna 1, Institute of Architecture and Urbanism, Batna, Algeria
[b] University of Oum El Bouaghi, Institute of Urban Technics Management, Oum el Bouaghi, Algeria

[c] Institut National des Sciences Appliquées de Lyon (INSA de Lyon), Department of Civil Engineering and

Urbanism, Environnement, Ville, société - EVS, UMR 5600, Centre National de Recherche Scientifique - CNRS,

Villeurbanne, France
\end{abstract}

How to cite: Guedoudj, W., Ghenouchi, A., \& Toussaint, J. Y. (2020). Urban attractiveness in public squares: the mutual influence of the urban environment and the social activities in Batna. urbe. Revista Brasileira de Gestão Urbana, 12, e20190162. https://doi.org/10.1590/2175-3369.012.e20190162

\section{Abstract}

This study examines how the components of the urban environment and its functionalities influence the attractiveness of public squares (PSs), and how they affect daily activities. This research is based on direct observations and surveys questionnaires. Data were collected from two PSs: May1st1945 square (MS, N=173) and Mohamed Harsous square (HS, N=97), located in Batna city centre (Algeria). The inquiry first includes an evaluation of urban environment layouts; a second evaluation to determine variables linked to environmental functionalities and utilization, and a third evaluation to assess social activities through characteristics of practices. The findings reveal that the components of the urban environment and its functionalities directly influence the attractiveness of PSs, mainly through proximity and comfort, and that shopping and leisure activities are also important for their attractiveness, but remain insufficient. This shows that attractiveness depends on the duration and variety of activities, including the interaction of people with these components to foster sociability. In addition, the use of these squares as a function of age and gender, and their appropriations are dealt with, since they have a direct effect on their uses and people's preferences.

Keywords: Public squares. Attractiveness. Urban environment components and functionalities. Sociability.

\section{Resumo}

Este estudo examina como os componentes do ambiente urbano e suas funcionalidades influenciam a atratividade das praças públicas (PSs) e como eles afetam as atividades diárias. Esta pesquisa é baseada em observações diretas e questionários. Os dados foram coletados em dois PSs: 1o de maio de 1945 praça (MS, $N=173$ ) e Mohamed Harsous praça (HS, $N=97$ ), localizada no centro da cidade de Batna (Argélia).

WG is assistant professor, PhD candidate, e-mail: wided.guedoudj@univ-batna.dz AG is PhD, lecturer, e-mail: ahmed.ghenouchi@yahoo.fr

JYT is professor, laboratory director, e-mail: jean-yves.toussaint@insa-lyon.fr 
O inquérito inclui uma primeira avaliação dos layouts do ambiente urbano; uma segunda avaliação para determinar variáveis ligadas às funcionalidades e utilização ambiental; e uma terceira avaliação para avaliar as atividades sociais através de características de práticas. Os resultados revelam que os componentes do ambiente urbano e suas funcionalidades influenciam diretamente a atratividade dos PSs, principalmente pela proximidade e conforto, e que as atividades de compras e lazer também são importantes para a atratividade, mas permanecem insuficientes. Demonstra-se que a atratividade depende da duração e variedade de atividades, incluindo a interação das pessoas com esses componentes, para promover a sociabilidade. Além disso, o uso desses quadrados em função da idade e do sexo, e suas apropriações, são tratados, uma vez que afetam diretamente seus usos e preferências das pessoas.

Palavras-chave: Praças públicas. Atratividade. Componentes do ambiente urbano e funcionalidades. Sociabilidade.

Abbreviations: Public Squares (PSS), Public spaces (PS), Urban environment (UE), Harsous square (HS), Maylst1945 (MS), "N" is indicated for the number of survey samples.

\section{Introduction}

The literature on urban design provides evidence of the importance of attractive PSs in supporting a sense of safety and pleasurable experiences (Childs, 2004; Cooper Marcus \& Francis, 1998) in public life (Gehl, 2004), where strangers enjoy a shared experience (Whyte, 1980). Anderson et al. 2017 (apud Mehta, 2007, 2013) stated that supporting high quality urban space may extend to the promotion of social and psychological health in modern communities.

In parallel, Pacheco (2017) explained in her publication (Ten principles for connecting people and streets) that public attractiveness depends on the vitality of public spaces.

The aim of this study is to investigate the importance of the components of the urban environment (EU) and its functionalities in attracting people to public squares (PSs), and how this attractiveness influences users' preferences in public life. By emphasizing the cultural and social aspects of people's activities and behaviour in this original research, we seek to understand the relationship between physical and social aspects and their influence on each other regarding the appeal of public spaces (PS).

The article focuses on two small urban squares in old Batna city centre (northeast Algeria), separated by (Republic Avenue), a central area that includes shops and services. A theatre forecourt - May 1st 1945 - also called (Pets Market) or (Elder Men's Place); and a square in front of the post office -Mohamed Harsous- also called (Cafés and Taxis Square). We observed that major socio-urban dynamics have emerged since the requalification of the two PSs in 2007 driven by a state planning policy. We wondered what brought people together in these two squares.

This study suggested two interrelated hypotheses. Firstly, the components of the UE -design and physical layout with urban functionalities- have a major impact on the influx of people; secondly, the utilization of UE facilities and the characteristics of people's practices in everyday activities may be the main reason why people prefer to come to PSs. This would imply that people attracted to PSs would in turn have an impact through their practices and behaviour on the attractiveness of a PS.

We collected data using different survey methods; document analysis, direct observation, and questionnaires, applying an ethnological approach conducted in-situ.

Our findings revealed that the components of the UE and its functionalities directly influence the attractiveness of PSs and contribute to urban dynamics. The survey conducted in-situ showed that certain design conditions like comfort, spatial proximity, and related activities like shopping are not enough to ensure permanent PS attractiveness. To a great extent attractiveness is made apparent by the duration and variety of practices produced by the social interactions involved in gathering and avoidance behaviours, as well as with the environment components, leading to sociability and liveliness. 
This article is divided into four parts, the first presents a review of the literature on the attractiveness of PSs, influenced by the UE, functionalities and social aspects. Then, the analytical framework and survey method are detailed, followed by the description of the case study and the findings. The article concludes with a discussion on the survey results that give orientations for future urban redevelopments and promotion through socio-cultural and economic activities in public squares.

\section{Background and literature review}

\section{The quality of a PS is based on a good balance between physical and social aspects}

PSs as PS are part of the UE; the aesthetic aspects, landscaping, facilities, and functionalities of this environment are what make it work, satisfy the needs of utilization and define urban and social assets. As Carmona et al. (2008) stated - Kit of parts - the most basic morphological character of a PS, represented by its constituents can be divided into four key elements; 1 . Buildings (Monuments, landmarks, etc.); 2. Landscape (street lights, bus stops, etc.); 3. Infrastructure (trees, street furniture, etc.); 4. Uses (events, gatherings, markets, etc.). The first three categories delineate the physical urban form that defines the limits of external public space, and between them create venues for human activity. The last element includes a set of human activities and is the most challenging to manage, giving public space its character.

According to the Projet for Public Space (2000), four key qualities are required for a high-quality UE: 1 . Access and linkages - appropriate to use, visible, easy to get to and move within-; 2. Uses and activities - providing a reason to be there, vital and unique-; 3 . Comfort and image, safe, clean, green, full of character and attractive-; 4. Sociability -fostering neighbourliness, friendship, interaction, diversity and pride-, as illustrated in (Figure 1).

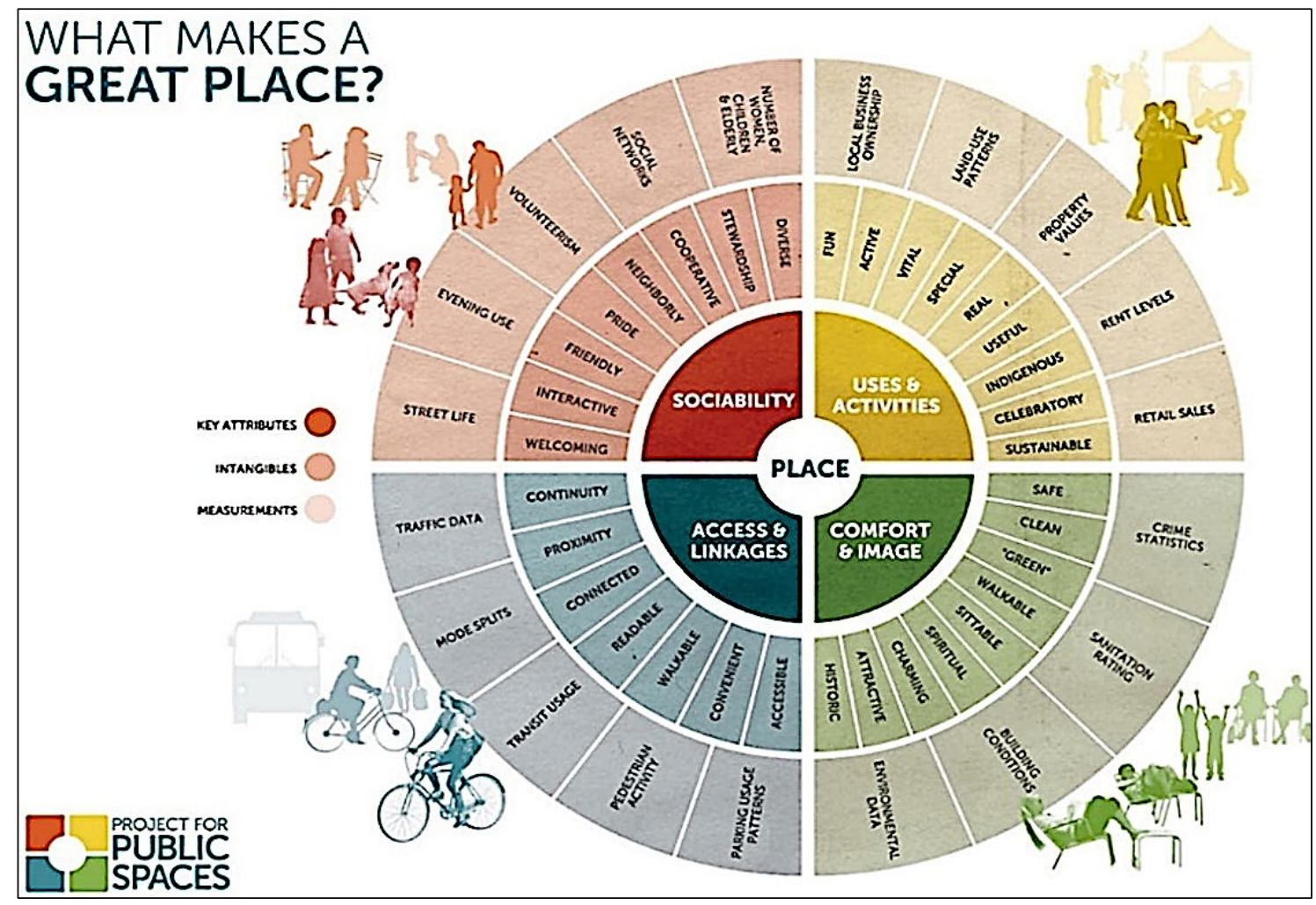

Figure 1 - Key attributes of successful places "The Place Diagram”. Source: Projet for Public Space (2000). 
A good balance between physical and social aspects is essential for urban life. Abu-Dayyeh (2018) said that it has always been a difficult quest to accomplish and mentioned strong criticisms and weaknesses in conceptualizing PS, reflecting the fact that one side has always taken priority over the other. The physical tendency is to place architectural design and profits first before social considerations about people living together. Regarding this, we first discuss our analysis on the impact of physical environment factors on the attractiveness of PS.

\section{The importance of the physical environment factors on the attractiveness of PS}

There are very few references in the literature that focus on the sole influence of physical aspects on PS quality. Gehl (1996) argued that factors like size, shape, connections, the spatial positioning of elements and their detailed design are important in determining the quality of public spaces and therefore the types of human activities they have to sustain (Carmona et al., 2003). Whyte (1980) provided observations on several public squares in New York with the following requirements: the good location of the PS - on a dynamic route, with significant physical and visual accessibility; integrated streets surrounding the public space; the more spaces are laid out on the same level, the more they are used, i.e. spaces should be level with the pavement; sitting places should be provided - both formal (e.g., benches, seats, etc.) and informal (e.g., steps, low walls, etc.).

As pointed out by many scholars, the comfort of an environment has an impact on its attractiveness, it includes perceptions about safety, cleanliness and the availability of places to sit. Maintenance is among the most important factors in successful place-making, ensuring comfort and increasing utilization. It is an often-ignored part of what must be considered an unending process (Hines, 2001).

This means that sustaining physical attributes facilitates public life within human activities, leading to a discussion on our second analysis of the influence of the social aspects of the PS attractiveness.

\section{The attractiveness of public spaces related to social aspects}

In the literature on public spaces, mention is made of the relative value of an UE and its functionalities with consideration on how its components are put together so as to promote the quality of public spaces and making them propitious for human activities. To this end, Carmona et al. (2008) put an accent on the preoccupation of the practicable aspect of the UE that directly influence how users perceive PS and their function and the social life taking place in them, thus involving their practicability for economic activities.

Furthermore, this should consider the social accessibility, as Harnik (2003) specified that the accessibility of a public space should be possible irrespective of social position (residency and financial income) and physical aptitudes, responding equitably to all the residents' needs, considering age, gender and accepting diversities and specific conditions.

In line with the standpoint of Gehl (1996 apud Carmona, 2015), which we integrate in this study, he explicitly claimed that the activities occurring in public spaces had impacts on people's perceptions of them. These activities are mainly related to the physical quality of the environment. He categorised outdoor activities into three categories: 1 . Necessary activities based on primary needs, i.e. walking to work, shopping for food, etc., are slightly influenced by the physical quality of the environment; 2. Optional activities that we choose in a favourable place and time, i.e. waiting for an appointment, window shopping, etc. They take place in optimal conditions and are thus a direct indicator of the public space's quality; 3 . Resultant activities, they depend on the presence of others in the public space, such as children playing, casual greetings, conversations, etc. Social activities are resultant because they occur spontaneously as a direct result of the other two forms of activities. They also affect users' perception of space because if people choose to stay in spaces rather than hurry through them, the space itself seems more liveable. 
In addition, activities are the basic building blocks of a place, as having something to do gives people a reason to come to a place. The more activities are included in a space, the more people have an opportunity to participate (Whyte, 2000). The intensity of life in public places is not only the product of the number of people, but rather the number of minutes spent in these public places (Gehl, 1996). Here, we emphasise the interaction process between people and the urban environment and its impacts on PS.

\section{The social attractiveness through the interaction with the urban environment}

The perception and the meaning we give to a place result from the interaction process between people and the environment. Ujang et al. (2018) reported on why people cherish some spaces and places and find them significant, because of their functional, emotional and social attachment to physical elements and activities. This is line with the results of Tanaka \& Kikata (2008) who linked the number of trees to rest activities and also longer-stay activities. Users specifically linked comfort and restfulness to the tree ratio besides feelings of well-being, relaxation and satisfaction. This indicates that different actions and behaviours within social activities are related to a stimulating element in the environment, that we perceive and interact with.

\section{A stimulating urban environment that affects its perception}

Davies (1992) observed the importance for a public space to have a good ambiance based on comfort and stimulating activities and uses to offer: animation, diversity and flexibility. An interesting space is one that stimulates the senses, visually, but also by sound, touch and smell.

Also, this can be achieved by exploiting the benefit of public art and by ensuring functional places through good lighting and signalling, etc.

Research on social sustainability highlights the role of public spaces in promoting the development of feelings, affiliation and belonging to a place, in addition to the development of strong social cohesion (Francis et al., 2012).

Regarding social environments, Ujang et al. (2018) observed the interaction of people and cultures within physical surroundings. (Barnett \& Casper, 2001) confirmed that human-place interaction influences human perceptions of a place that give places an identity, while the experiential value of a place is derived from users' interactions with its associated attributes (Marans, 2012; Ujang, 2014). This explains that interaction influences the quality of PS and its attendance.

\section{A valuable public space through the interaction between people}

In a pertinent article with which we strongly agree, Richaud (2018) mentioned that social activities influence the types of relationship between people in public spaces, so people's behaviours in turn impact activities. In terms of affect and emotional intensity, the presence of individuals together in collective activities leads to a sense of emotional intimacy (Morgan 2009). Developed within certain social activities, intimacy has -contingent upon its forms of expression - (Rapport, 1999) - an effect on the behaviour of actors - (Latour, 2005; see also Steinmuller, 2011) by interpreting attachment to convivial places as a collective, social response to an ongoing process in which the present, itself, is being erased by a shifting urban landscape (Mele et al., 2015).

On the basis of the literature mentioned above, which we consider explicitly deals with the multiple factors that influence the attractiveness of public squares, we will develop the method adopted in our case study in the following part. 


\section{Methods}

The findings of the case study conducted over a period of three years required cross-disciplinary methods with several surveys and a qualitative approach to data collection (Low et al., 2005). It first consists of a document survey performed on an iconographic method (based on maps and photographs) to compile sociodemographic data with users' characteristics and strengthen the description of the environment studied; further in-situ surveys: an ethnological method based on observation, questionnaires and time-lapse photography analyses. The in-situ investigation was conducted on weekdays, weekends and event days (national and religious events, and exhibitions); during mornings, afternoons and evenings; with an observation duration of (30-45) minutes in good weather conditions (to be sure to find and observe people and activities in PSs).

The observation notes were taken directly in the field and indirectly by maintaining a distance (at exact observation points, e.g., in a parked car and at street corners); the questionnaire results were reported in situ in a logbook, schematic maps and then on structural grids and tables (Guedoudj, 2013). Our case study (the city and the two PSs) are described in detail in the following sections.

\section{Sites and sample}

The city of Batna is located in northeast Algeria and $135 \mathrm{~km}$ southeast from the capital, Algiers. With a surface area of $82 \mathrm{~km}^{2}$, it is the capital of the Aures region, and is the 5th largest city in the country. It has 375,000 inhabitants and 12 urban sectors, as indicated in (Figure 2).

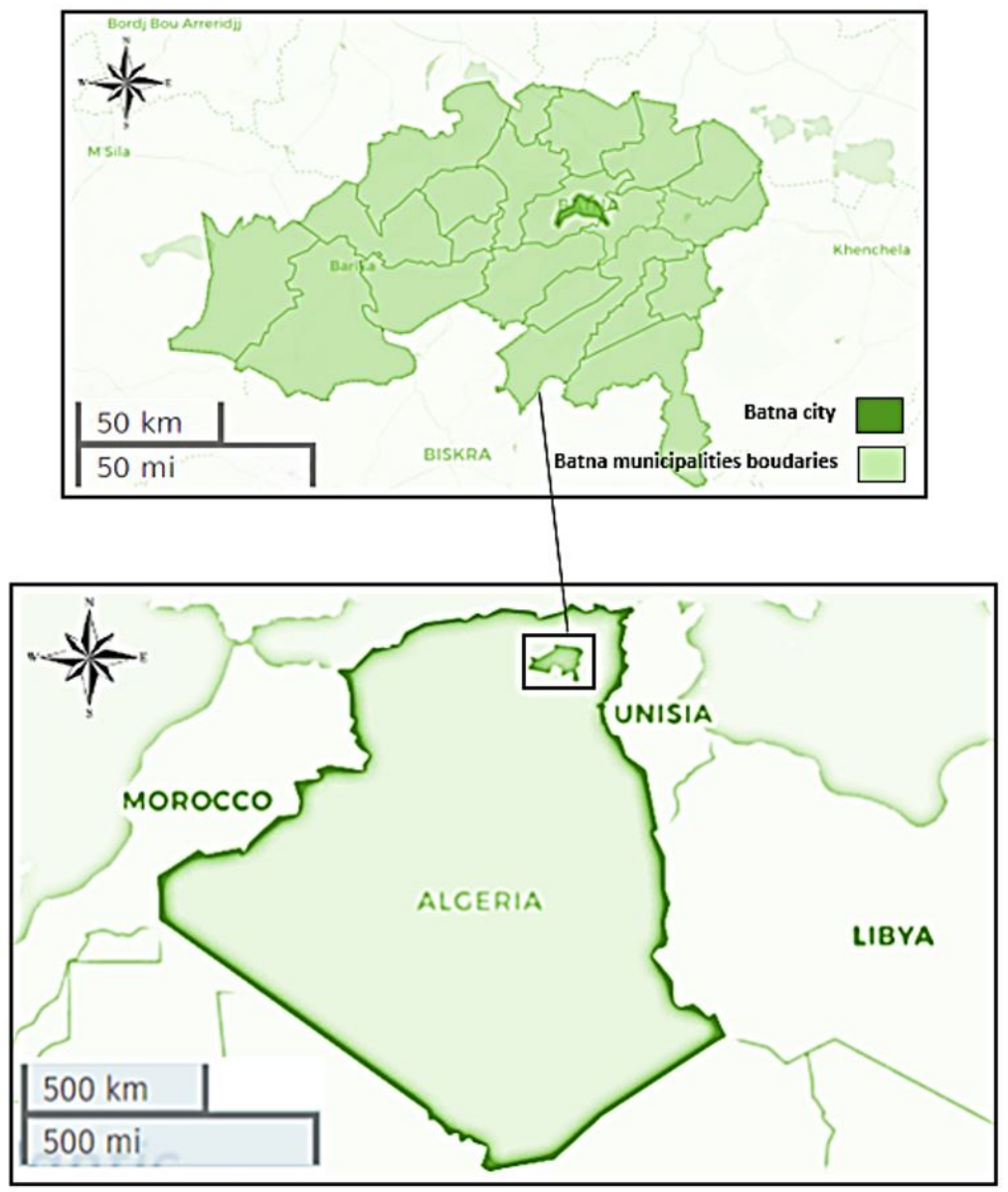

Figure 2 - The location of Batna in Algeria and its municipalities boundaries. Source: Geographic data and processed by the author. 
The city attracts people from all over the country, for cultural and national events, shopping, and touristic visits of its natural and ancient archaeological sites (Marin, 2005).

The public squares of the city of Batna, which provide the specific subject matter for the case study, are situated in the city centre dating back to the old colonial period, and they have witnessed most of the country's important historical, political, economic and social changes (Cote, 1991). That is what makes its PSs the receptacle of socio-urban dynamics and sociability, reflecting cultural and urban vitality. The main activities in the study area are necessary activities, mostly commercial, transport, and services (Figure 3, and Figure 4).

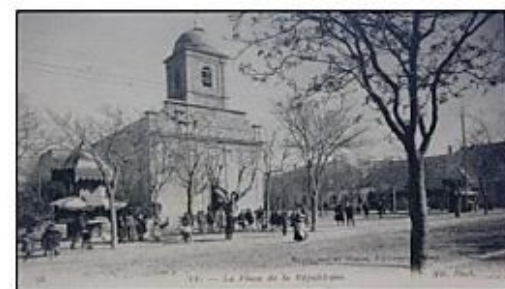

a. The old church and the two kiosks, Source: www.delcampenet

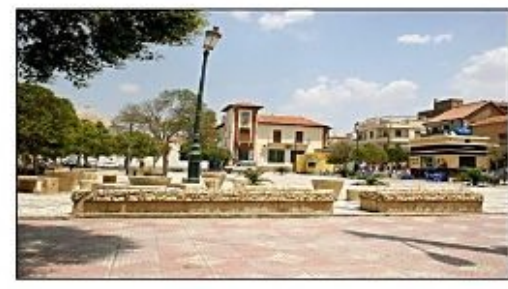

c. The tiled paving and stones benches after the remove of the water basin. Source: Web sile @ unknown phologropher, 2005

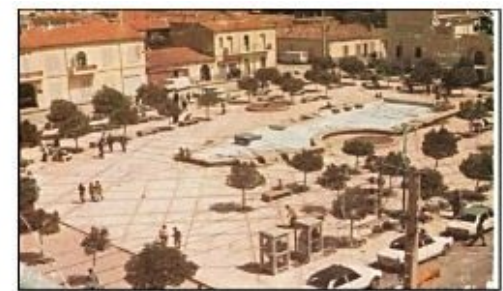

b. The marble pavement, the water basin and the telephone booths after the remove of the church and the kiosks. Source: The cuthor's post card, 80's 9 unknown photographer.

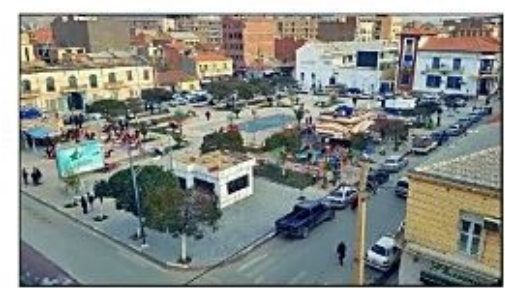

d. The nowadays layout with the two transformed kiosks to coffee shops, and the new water-jet. Source: Web sile, Maamri pholography, 2017.

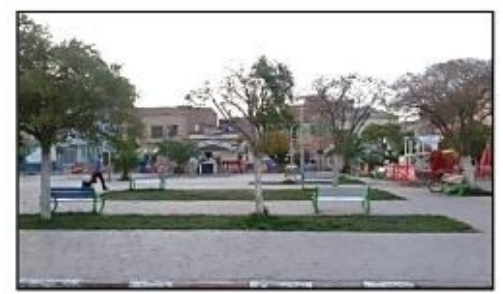

f. The square at its lower time of frequentation in summer day June 2018, at 5 am with the new wooden benches and the café-terraces facilities. Source: Master student; (Chalissa Hamous.

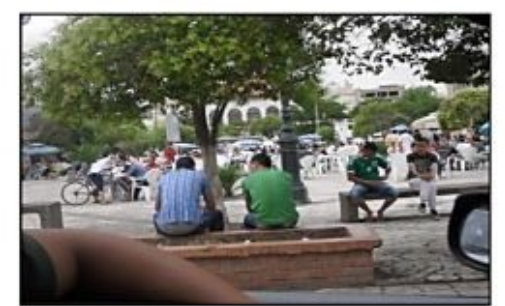

h. The bins of greenery as a setting possibility, a kind of appropriation in periods of large influx. Source: The author, July 2012.

Figure 3 - Harsous square with its main layout, urban changes and uses. 


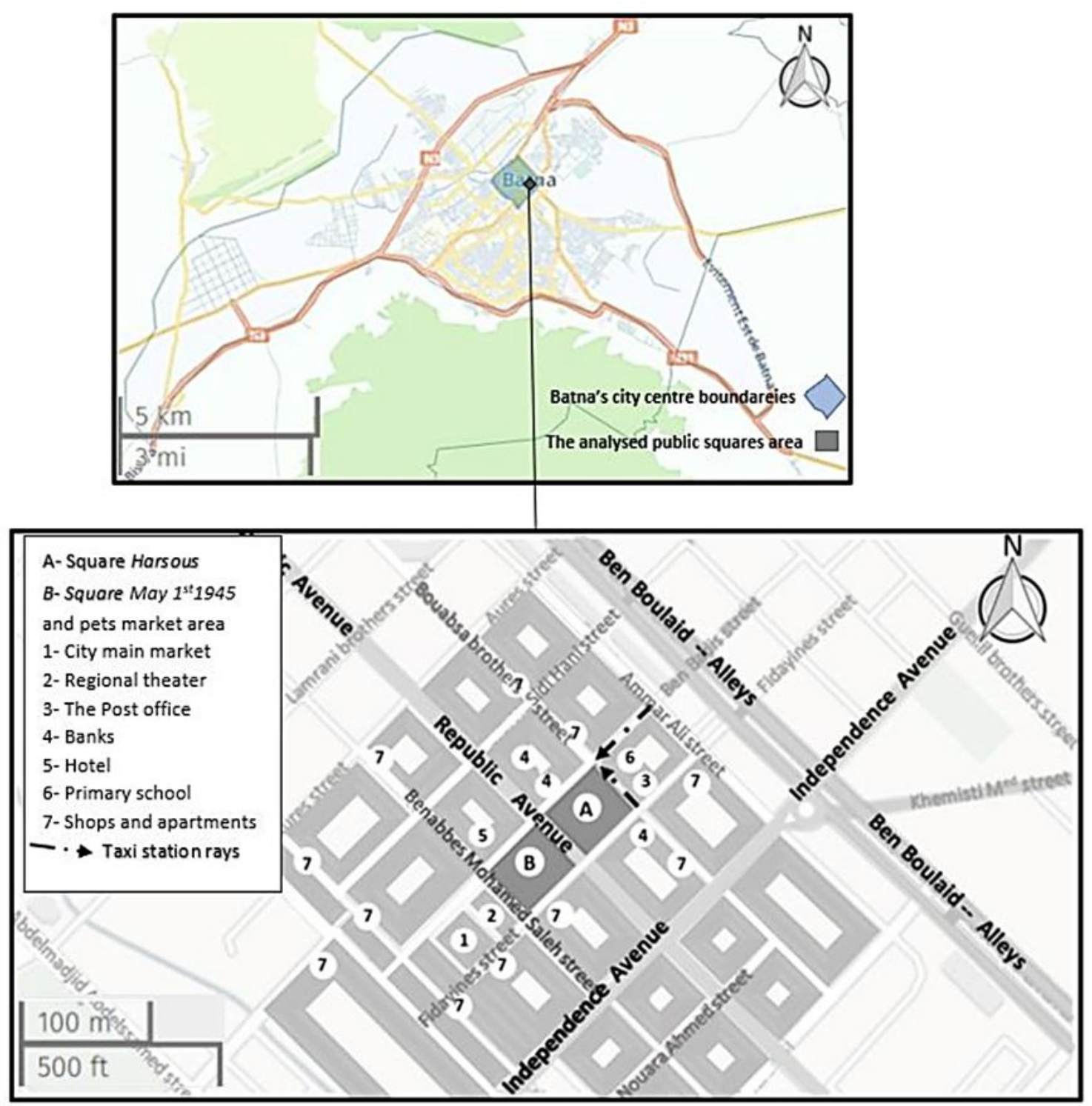

Figure 4 - The squares analysed "Harsous square" and "regional theatre Square" and their surrounding area in Batna city. Source: Geographic data \& processed by the autor 2019.

Its planning policy process is like that of most of the country's cities, characterised by very rapid urbanisation, generally oriented to solve housing problems resulting from demographic expansion and the rural exodus. In addition, its public spaces have been subject to standardized planning for a long period.

We have witnessed new socio-cultural dynamics since the implementation of new layout and landscaping treatments that have transformed the environment of public squares (paving, greening, water and seating facilities, etc.). This was due to the introduction of the "Urban Development Program in 2007" which was part of the urban redevelopment policy to reinvest public spaces after "the law on urban orientation" was passed. The urban policy that governs these spaces remains strongly influenced by the major socio-political and economic events that the country has experienced, that we summarize in five main points in (Table 1). 
Table 1 - The urban evolution of PSs and its impacts

\begin{tabular}{|c|c|c|c|c|c|}
\hline $\begin{array}{c}\text { The urban } \\
\text { evolution in } \\
\text { periods }\end{array}$ & $\begin{array}{c}\text { French } \\
\text { colonial PSs }\end{array}$ & $\begin{array}{c}\text { An inherited } \\
\text { patrimonial PS }\end{array}$ & $\begin{array}{l}\text { Economical } \\
\text { crisis with } \\
\text { unmanaged } \\
\text { urban planning }\end{array}$ & $\begin{array}{c}\text { The impacts of } \\
\text { the black } \\
\text { decade }\end{array}$ & $\begin{array}{l}\text { A massive urban } \\
\text { transformations }\end{array}$ \\
\hline $\begin{array}{c}\text { The period } \\
\text { duration }\end{array}$ & (1844-1962) & (1962-1980) & (1980-1990) & (1990-2000) & $\begin{array}{c}\text { (2000- } \\
\text { nowadays) }\end{array}$ \\
\hline $\begin{array}{c}\text { The } \\
\text { Characteristics } \\
\text { (political, } \\
\text { economic, } \\
\text { social) of the } \\
\text { periods }\end{array}$ & $\begin{array}{l}\text { - Based on } \\
\text { European } \\
\text { "Haussmann } \\
\text { style" town } \\
\text { planning } \\
\text { standards, full } \\
\text { of vegetation; } \\
\text { - Dedicated to } \\
\text { trading, leisure, } \\
\text { hosting events } \\
\text { and civic } \\
\text { celebrations. }\end{array}$ & $\begin{array}{l}\text { - Symbolising the } \\
\text { liberation and } \\
\text { revolution; } \\
\text { Spaces of } \\
\text { artistic, industrial } \\
\text { and trade shows } \\
\text { (Guedoudj } \\
\text { 2013). }\end{array}$ & $\begin{array}{l}\text { - Marginal use } \\
\text { during the most } \\
\text { important } \\
\text { economic crisis in } \\
\text { which the state left } \\
\text { PS to abandon } \\
\text { and insecurity } \\
\text { (Hafiane, 2007), } \\
\text { after which } \\
\text { squatting and } \\
\text { vandalism took } \\
\text { over. }\end{array}$ & $\begin{array}{l}\text { - Known as a } \\
\text { "civil war" } \\
\text { (Rahal, 2017), } \\
\text { terrorism and } \\
\text { government } \\
\text { policy repressed } \\
\text { freedom to use } \\
\text { public spaces } \\
\text { and closed off } \\
\text { PSs for control } \\
\text { and security } \\
\text { purposes } \\
\text { (Naceur, 2007). }\end{array}$ & $\begin{array}{c}\text { To reinvest, } \\
\text { promote and } \\
\text { improve urban } \\
\text { quality following } \\
\text { the urban } \\
\text { enhancement } \\
\text { programme and } \\
\text { which has been } \\
\text { accompanied } \\
\text { by the } \\
\text { expression of a } \\
\text { wide range of } \\
\text { social } \\
\text { behaviours and } \\
\text { practices, } \\
\text { mainly linked to } \\
\text { leisure, art and } \\
\text { trade shows, etc } \\
\text { (Naceur, 2017). }\end{array}$ \\
\hline
\end{tabular}

Source: The author (2019).

\section{Mohamed Harsous: Republic square}

Built in 1855 as a church forecourt and consecrated in 1863, it was mainly used for hosting national festivities (such as the ball of July 14th). It extended the square in front of the theatre. Social and religious celebrations, wedding ceremonies, and Saturdays masses were held there. After the church was removed, with the two old multi-service kiosks, the space was replaced by a marble paved square in 1970, a large water basin, and stone benches, clearly seen in (Figure 3).

It is located in the central shopping area, on the north side of Republic Avenue; facing the theatre square, and occupied by two banks, the post office, a school, and also surrounded by many ground-floor stores with apartments on higher floors, and a taxi rank.

It has been renovated several times, including in the 1990s, with the removal of the water basin and the addition of new tiled paving and steel benches, the disappearance of telephone booths, with the advent of the mobile phone, and the addition of four multi-service kiosks. Since 2007 it has been subject to two new refurbishments, principally new pavements, wooden benches to replace the stone ones, a new water jet, and a large screen on the post office wall for public broadcasts of football matches, and two old kiosks turned into two small coffee shops, see (Figure 4 and Figure5). 


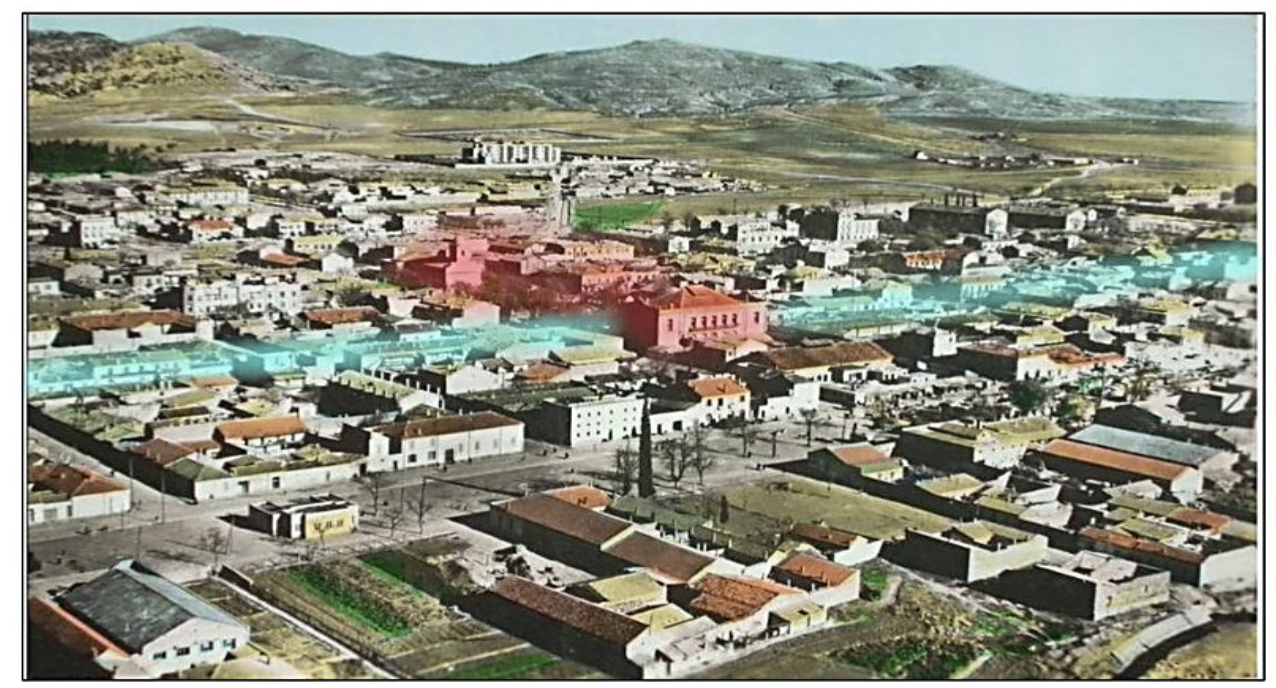

Figure 5 - The old church of Harsous square in front of the theatre and its square (in light red), separated by the Republic Avenue (in light blue) in the old city centre of the colonial period. Source: The archive of the author (Delcampe International, 2019) and processed by the autor 2019.

Both a crossroads square and forecourt, it represents a city landmark, a space of celebrations, relaxation, and meetings, occupied by the young and elderly male population.

\section{May 1st 1945: regional theatre square}

Created in 1899 for relaxation and cultural exhibitions in continuity with the theatre, with a bandstand in the middle, replaced by a fountain between (1978-1991); it has received several successive facilities, reducing the planted area, with the addition of two kiosks, public toilets, and a new surface pavement. The fountain was definitively removed, and a new vehicle-parking alley now separates the square from the theatre.

Located in Republic Avenue, facing Harsous square and the post office, there is a hotel to the left, ground floor stores and apartments on higher floors. Near the theatre forecourt, there is another hotel and the main old market of the city and its haberdashery stalls "Rahba", see also (Figure 4 and Figure 5). It is well-known as a pet 'market on weekends, for everyday market selling and display activities, and cars can park in the surrounding streets. It is also used for commercial and artistic activities and national exhibitions, and social demonstrations are held there. It has recently been subjected to new layouts, mainly the replacement of the pavement with a new water fountain and wooden benches replacing the steel ones, depicted in (Figure 6). 


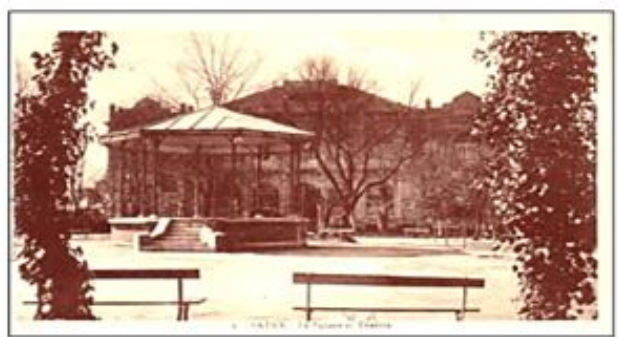

a. The old kiosk and the wooden benches. Source: www.delcampe.net.

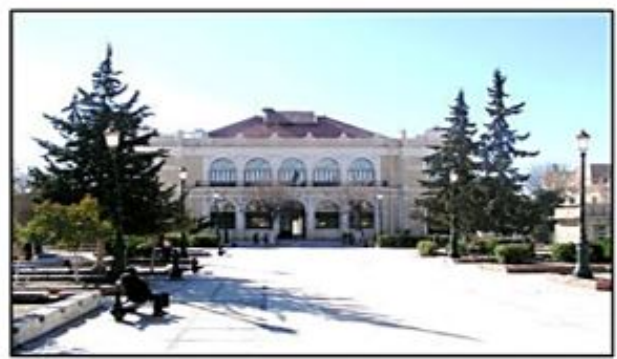

c. The pavement replaces the kiosk and the fountain with the greenery in different design and benches in steel. Source: @ Mebarki Rym, 2011.

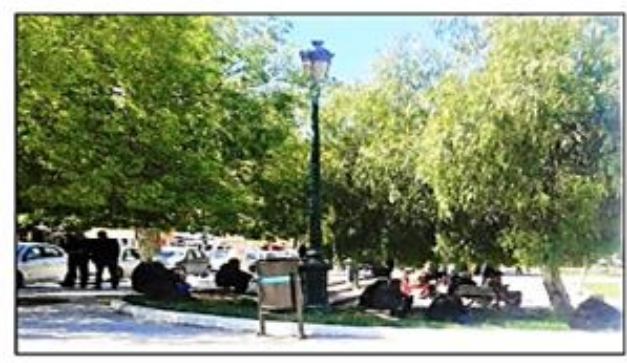

e. Resting and waiting for RDV on the grass of the square's corners. Source: The author, 2018.

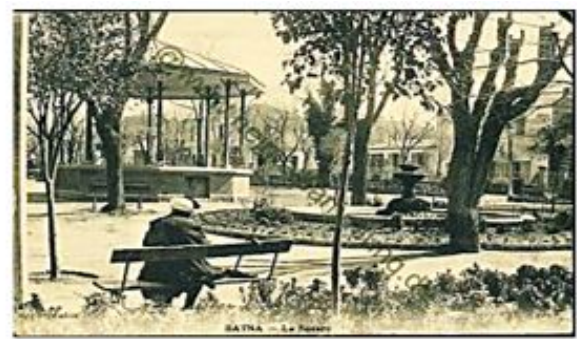

b. The old water fountain with its dense greenery. Source : www.delcampe,net

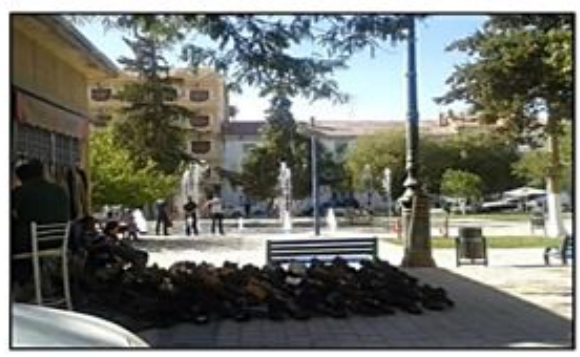

d. The new water jet and the new square's ambiance, with the kiosk-shop clothing sales display and the new wooden benches. Source: The author, 2018.

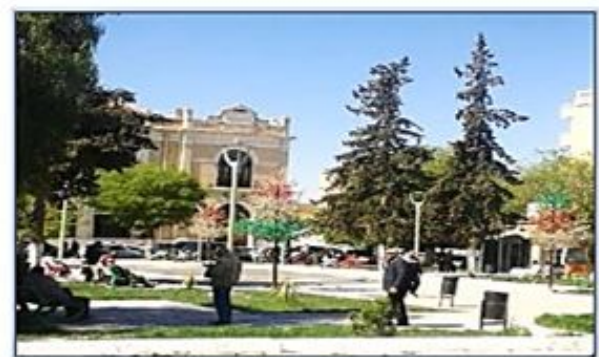

f. Sunbathing, waiting in standing or sitting positions, crossing or just passing by the square. Source: The author, 2018.

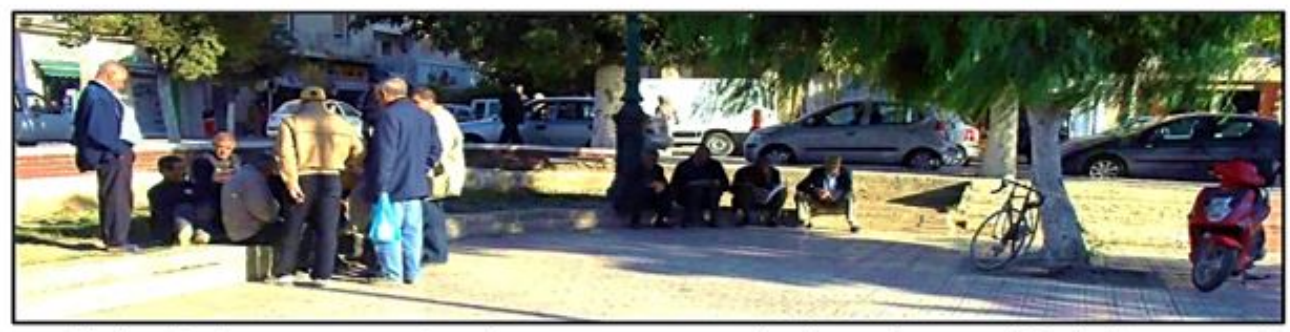

g. Playing Kharbga game, and reading newspapers; another form of appropriation in the corner of the square: with a poverty in the design, materials and in the maintenance of the layout.

Source: The author,2011.

Figure 6 - The theatre square through time (layouts, uses, and behaviours).

It is a space of relaxation, meetings, play for young and old people, generally with mixed attendance.

We will discuss in the section on data collection and analysis, the analysis of the data collected and its treatment. The data are represented in three detailed tables, and followed by the results section and the discussion. 


\section{Data collection and analysis}

The data was collected from a concise construct which contains attributes referenced with the research concepts, dimensions and criteria mentioned in the literature review above, and combined with information collected in the field to determine the PSs attractiveness.

We first needed to collect sociodemographic characteristics about PS users to obtain information in our inquiry sampling, using a questionnaire ${ }^{1}$, see (Table 2). Data are based on (gender, age, education level and occupation situation) to determine through the social activities carried out in the squares whether they are places of diversity or uniformity; equity or injustice.

We also checked the impacts of distance and accessibility; being a resident or a visitor can influence PS occupation and stay duration. In addition, getting to the area by car, bus or on foot, has an influence on the attractivity and users' behaviours and preferences.

Table 2 - Users' sociodemographic characteristics

\begin{tabular}{|c|c|c|c|c|c|}
\hline \multirow{2}{*}{\multicolumn{2}{|c|}{ Users' characteristics and categorizations }} & \multicolumn{4}{|c|}{ Public square respondents } \\
\hline & & \multicolumn{2}{|c|}{ Harsous square $(H S)^{2}$} & \multicolumn{2}{|c|}{ May $1^{\text {st }} 1945$ square $(M S)^{3}$} \\
\hline & & $\left(N^{4}=97\right)$ & (\%) & $(N=173)$ & (\%) \\
\hline \multirow[t]{2}{*}{$\underline{\text { Gender }}$} & Female & 07 & 7.22 & 59 & 34.10 \\
\hline & Male & 90 & 92.78 & 114 & 65.90 \\
\hline \multirow[t]{5}{*}{ Age } & $12-18$ & 02 & 2.06 & 11 & 6.36 \\
\hline & $19-24$ & 12 & 12.37 & 03 & 1.73 \\
\hline & $25-40$ & 35 & 36.08 & 42 & 24.28 \\
\hline & $41-65$ & 17 & 17.53 & 56 & 32.37 \\
\hline & +65 & 31 & 31.96 & 61 & 35.26 \\
\hline \multirow{2}{*}{$\begin{array}{c}\text { Housing } \\
\text { characteristics }\end{array}$} & Resident & 75 & 77.30 & 122 & 70.52 \\
\hline & Visitor & 22 & 22.6 & 51 & 29.48 \\
\hline \multirow[t]{2}{*}{ House distance } & Near & 71 & 73 & 130 & 75.14 \\
\hline & Far & 26 & 26.8 & 43 & 24.86 \\
\hline \multirow[t]{3}{*}{ Transportation mode } & Walking & 45 & 46.3 & 85 & 49.13 \\
\hline & Car ownership & 19 & 19.5 & 60 & 34.68 \\
\hline & Public transportation & 33 & 34 & 28 & 16.19 \\
\hline \multirow[t]{4}{*}{ Education level } & Illiterate & 10 & 10.3 & 22 & 12.72 \\
\hline & Primary school & 24 & 24.8 & 40 & 23.12 \\
\hline & Secondary school & 31 & 32 & 45 & 26.01 \\
\hline & University & 32 & 32.9 & 66 & 38.15 \\
\hline \multirow[t]{4}{*}{ Occupation situation } & Student & 22 & 22.7 & 29 & 16.76 \\
\hline & Employed & 31 & 32 & 58 & 33.53 \\
\hline & Unemployed & 27 & 27.8 & 23 & 13.29 \\
\hline & Retired & 17 & 17.5 & 63 & 36.42 \\
\hline
\end{tabular}

Source: The author (2018).

\footnotetext{
${ }^{1}$ We adopted five kinds of question: 1. Filter question to get information on (age, gender, transportation modes...); 2. Dichotomic questions (closed questions to which the respondent can answer by one of two possibilities A or B; Yes or No) e.g., "do you feel comfortable on this bench?" A. yes, B. No, often followed by a Conditional question (conditioned by the previous answer used to develop the discussion) e.g., "what bothers you most about using this bench?"; 3. Multiple choice question "MCQ check boxes" e.g. "Who accompanies you during your visits to PSs? A. Neighbour, B. Friend, C. Child,.."; 4. Evaluation grid “Likert scale" by choosing from 1 to 5 answer propositions ranging from very satisfied (e.g., with the lighting devices) to very disappointed; 5. Open-ended response questions, e.g., "How did you get to this place?", i.e. The respondent would like to explain how and why they arrived at the place, and to describe the manner, the means and the constraints that they found when arriving to obtain more details and elements to expand the questionnaires.

2 (HS) acronym of Harsous square.

${ }^{3}$ (MS) acronym of May $1^{\text {st }} 1945$ square.

${ }^{4}(\mathrm{~N})$ acronym used for the number of survey samples.
} 
Then, we categorized data into two parts;

1. Urban environment components, facilities and functionalities (Table 3), determined by information obtained from the in-situ enquiry: direct observations with spatial analysis and questionnaires evaluated for the two PSs. The evaluation criteria are based on: a/ Physical environment aspects and mechanisms and their interaction with users (spatial accessibility, layout; access conditions, socio-spatial proximity with transportation facilities); b/ Level of comfort and the quality of public facilities (safety from traffic and crime; i.e. the provision of sufficient lighting, road marking and signage; weather conditions and facility management; the supply and effectiveness of shading, wind screens, with multiple setting possibilities); and c/ Aesthetic and landscape perception which rely on the degree of agreeableness and physical maintenance of the PSs with satisfaction regarding their attractiveness and distinctiveness;

Table 3 - Evaluating urban environment components, facilities and functionalities

\begin{tabular}{|c|c|c|c|c|c|c|c|c|}
\hline \multirow{2}{*}{$\begin{array}{l}\text { UE components } \\
\text { (PS } \\
\text { attractiveness } \\
\text { indicators }\end{array}$} & \multicolumn{2}{|c|}{$\begin{array}{c}\text { Public squares } \\
\text { Observations and questionnaire } \\
\text { results }\end{array}$} & \multicolumn{6}{|c|}{ Participants' evaluations: total $N=\mathbf{2 7 0}$} \\
\hline & $\begin{array}{c}\text { Harsous } \\
\text { Square HS }\end{array}$ & $\begin{array}{c}\text { May } 1^{\text {st }} 1945 \\
\text { Square MS }\end{array}$ & \multicolumn{2}{|c|}{$H S:(N=97)$} & \multirow{2}{*}{$\begin{array}{c}\text { (\%) } \\
9.28 \%\end{array}$} & \multicolumn{2}{|c|}{$M S:(N=173)$} & (\%) \\
\hline \multirow{2}{*}{$\begin{array}{l}\text { Accessibility } \\
\text {-Access } \\
\text { conditions; } \\
\text { street, ways and } \\
\text { sidewalks layouts } \\
\text { and comfort. }\end{array}$} & \multirow{2}{*}{\multicolumn{2}{|c|}{$\begin{array}{l}\text { 5*A restrictive access from all } \\
\text { sides; } \\
\text {-Unsafe footpaths \& sidewalks } \\
\text { with presence of cars parking } \\
\text { and stairs in (MS). } \\
\text { * Rough pavement \& rugged } \\
\text { corners. }\end{array}$}} & ${ }^{6}$ Effective & 9 & & Effective & 23 & $13.29 \%$ \\
\hline & & & $\begin{array}{c}{ }^{7} \text { Not } \\
\text { effective }\end{array}$ & 88 & $90.72 \%$ & $\begin{array}{c}\text { Not } \\
\text { effective }\end{array}$ & 150 & $86.71 \%$ \\
\hline \multirow{2}{*}{$\begin{array}{l}\text {-Proximity: } \\
\text { Distance from } \\
\text { neighbourhood, } \\
\text { daily activities \& } \\
\text { locations. }\end{array}$} & \multirow{2}{*}{\multicolumn{2}{|c|}{$\begin{array}{l}\text { *Very good proximity with } \\
\text { neighbourhood, shopping and } \\
\text { other services. } \\
\text { *Ability to find destination within } \\
5 \text { - } 10 \text { minutes. } \\
\text { *Interesting destinations to walk } \\
\text { to. }\end{array}$}} & Effective & 95 & $97.94 \%$ & Effective & 96 & $55.50 \%$ \\
\hline & & & $\begin{array}{c}\text { Not } \\
\text { effective }\end{array}$ & 2 & $2.06 \%$ & $\begin{array}{c}\text { Not } \\
\text { effective }\end{array}$ & 77 & $40.50 \%$ \\
\hline \multirow{2}{*}{$\begin{array}{c}\text {-Transportation } \\
\text { facilities }\end{array}$} & \multirow{2}{*}{\multicolumn{2}{|c|}{$\begin{array}{l}{ }^{*} \text { Good public transport } \\
\text { accessibility (bus stop close by), } \\
\text { bad accessibility by cars } \\
\text { (parking alleys filled with } \\
\text { congested road traffic). }\end{array}$}} & Effective & 71 & $73.20 \%$ & Effective & 135 & $78.03 \%$ \\
\hline & & & $\begin{array}{c}\text { Not } \\
\text { effective }\end{array}$ & 26 & $26.80 \%$ & $\begin{array}{c}\text { Not } \\
\text { effective }\end{array}$ & 38 & $21.97 \%$ \\
\hline \multirow{2}{*}{$\begin{array}{l}\text { Comfort \& public } \\
\text { facilities } \\
\text {-Safety from } \\
\text { crime \& traffic }\end{array}$} & \multirow{2}{*}{\multicolumn{2}{|c|}{$\begin{array}{c}\text { *Poor street lighting, no } \\
\text { integration of CCTVs (security } \\
\text { systems); } \\
\text { *Poorly maintained cycling path } \\
\text { with traffic calming features; } \\
\text { *Dangerous street crossing } \\
\text { conditions (unclear road } \\
\text { marking and lack of signalling). }\end{array}$}} & Effective & 15 & $15.46 \%$ & Effective & 77 & $44.51 \%$ \\
\hline & & & $\begin{array}{c}\text { Not } \\
\text { effective }\end{array}$ & 82 & $84.54 \%$ & $\begin{array}{c}\text { Not } \\
\text { effective }\end{array}$ & 96 & $55.49 \%$ \\
\hline \multirow{2}{*}{$\begin{array}{l}\text {-Weather } \\
\text { conditions \& } \\
\text { facilities } \\
\text { management }\end{array}$} & \multirow{2}{*}{$\begin{array}{l}\text {-Coffee shops } \\
\text { provide } \\
\text { some } \\
\text { removable } \\
\text { sunshade } \\
\text { layouts; }\end{array}$} & \multirow{2}{*}{$\begin{array}{l}\text { - Areas } \\
\text { unprotected } \\
\text { from weather } \\
\text { conditions, } \\
\text { despite the } \\
\text { lack of } \\
\text { shaded } \\
\text { places. }\end{array}$} & Effective & 38 & $37.11 \%$ & Effective & 29 & $16.76 \%$ \\
\hline & & & $\begin{array}{c}\text { Not } \\
\text { effective }\end{array}$ & 61 & $62.89 \%$ & $\begin{array}{c}\text { Not } \\
\text { effective }\end{array}$ & 144 & $83.24 \%$ \\
\hline
\end{tabular}

5 The symbol $(*)$ In (Table 3): represents common survey notes and results for both squares.

6 The two qualifiers; (effective) with its negative form (not effective) mentioned in (Table 3) are used to determine the degree of the (acceptability, appreciation and satisfaction), with operational usability of the of the space and the layout (sufficiency, practicability, and durability) of the users toward the urban environment components and its functionalities;

7 The numbers that follow the qualifier; e.g. (effective: 9/9.28), i.e. (9) signifies the number of responses from the total questionnaire number (97) collected in Harsous square. (9.28\%) represents rather the percentage from (100\%) of total questionnaires. 
Table 3 - Continued....

\begin{tabular}{|c|c|c|c|c|c|c|c|c|}
\hline \multirow{2}{*}{$\begin{array}{l}\text { UE components } \\
\text { (PS } \\
\text { attractiveness } \\
\text { indicators }\end{array}$} & \multicolumn{2}{|c|}{$\begin{array}{c}\text { Public squares } \\
\text { Observations and questionnaire } \\
\text { results }\end{array}$} & \multicolumn{6}{|c|}{ Participants' evaluations: total $\mathbf{N}=\mathbf{2 7 0}$} \\
\hline & $\begin{array}{c}\text { Harsous } \\
\text { Square HS }\end{array}$ & $\begin{array}{c}\text { May } 1^{\text {st }} 1945 \\
\text { Square MS }\end{array}$ & HS: $(N=97$ & & (\%) & MS: $(N=$ & & (\%) \\
\hline \multirow{2}{*}{$\begin{array}{l}\text {-Seating } \\
\text { possibilities }\end{array}$} & \multicolumn{2}{|c|}{$\begin{array}{l}\text { *Fixed seating with wood } \\
\text { benches, planted pots also used } \\
\text { for seating. }\end{array}$} & Effective & 24 & $24.74 \%$ & Effective & 29 & $16.76 \%$ \\
\hline & $\begin{array}{l}\text { - Coffee shops } \\
\text { provide plastic } \\
\text { benches. }\end{array}$ & $\begin{array}{c}\text { - Corners' stairs } \\
\text { used as sitting } \\
\text { zone. }\end{array}$ & $\begin{array}{c}\text { Not } \\
\text { effective }\end{array}$ & 73 & $75.25 \%$ & $\begin{array}{c}\text { Not } \\
\text { effective }\end{array}$ & 145 & $84 \%$ \\
\hline \multirow[b]{2}{*}{-Public facilities } & \multicolumn{2}{|c|}{$\begin{array}{l}\text { *Lack of modern, aesthetic \& } \\
\text { maintained facilities: garbage } \\
\text { cans, play and physical } \\
\text { activities, play spaces, parking } \\
\text { spaces and bicycle places, } \\
\text { physical activity facilities, }\end{array}$} & Effective & 22 & $22.68 \%$ & Effective & 57 & $32.53 \%$ \\
\hline & $\begin{array}{l}\text {-Non- } \\
\text { functional } \\
\text { water-jet; } \\
\text {-Users don't } \\
\text { feel comfort } \\
\text { with children } \\
\text { playing } \\
\text { around. }\end{array}$ & $\begin{array}{l}\text {-Functional } \\
\text { water-jet, } \\
\text { becomes } \\
\text { children } \\
\text { playground; } \\
\text {-Users aren't } \\
\text { bothered by } \\
\text { playing } \\
\text { around. }\end{array}$ & $\begin{array}{c}\text { Not } \\
\text { effective }\end{array}$ & 75 & $77.32 \%$ & $\begin{array}{c}\text { Not } \\
\text { effective }\end{array}$ & 115 & $66.47 \%$ \\
\hline$\frac{\text { Aesthetics \& }}{\text { landscape }}$ & \multicolumn{2}{|c|}{$\begin{array}{l}\text { *An aesthetic architectural and } \\
\text { urban landscape; } \\
\text { *Lack of maintenance of old } \\
\text { neo-classical façades; lack of } \\
\text { new architectural facade styles; } \\
\text { increased degradation of } \\
\text { plants; } \\
\text { *Good cleanliness but could } \\
\text { become better. }\end{array}$} & - & - & - & - & - & - \\
\hline \multirow[b]{2}{*}{$\begin{array}{l}\text {-Pleasance and } \\
\text { maintenance } \\
\text { with satisfaction }\end{array}$} & \multirow{2}{*}{$\begin{array}{l}\text {-Attracted by } \\
\text { the coffee } \\
\text { shops seating } \\
\text { facilities } \\
\text { amenities } \\
\text { users \& } \\
\text { proximity of } \\
\text { amenities; }\end{array}$} & \multirow{2}{*}{$\begin{array}{l}\text { - Attracted by } \\
\text { the space and } \\
\text { activities, } \\
\text { distribution, } \\
\text { facilities \& } \\
\text { proximity; }\end{array}$} & Effective & 9 & $9.28 \%$ & Effective & 36 & $20.81 \%$ \\
\hline & & & $\begin{array}{c}\text { Not } \\
\text { effective }\end{array}$ & 88 & $90.72 \%$ & $\begin{array}{c}\text { Not } \\
\text { effective }\end{array}$ & 137 & $79.19 \%$ \\
\hline \multirow[b]{2}{*}{$\begin{array}{l}\text {-Place } \\
\text { attraction, } \\
\text { satisfaction \& } \\
\text { distinctiveness }\end{array}$} & \multirow{2}{*}{$\begin{array}{l}\text { - Appreciation } \\
\text { of all-day lively } \\
\text { ambiance, } \\
\text { sharing friends } \\
\text { \& neighbours; } \\
\text {-A very } \\
\text { crowded } \\
\text { place. }\end{array}$} & \multirow{2}{*}{$\begin{array}{l}\text { - Appreciation } \\
\text { of the calm } \\
\text { ambiance, } \\
\text { being with } \\
\text { friends \& } \\
\text { family; } \\
\text { - A less } \\
\text { crowded } \\
\text { place, except } \\
\text { during events. }\end{array}$} & Effective & 70 & $72.16 \%$ & Effective & 122 & $70.52 \%$ \\
\hline & & & $\begin{array}{c}\text { Not } \\
\text { effective }\end{array}$ & 27 & $27.84 \%$ & $\begin{array}{c}\text { Not } \\
\text { effective }\end{array}$ & 51 & $29.48 \%$ \\
\hline
\end{tabular}

Source: The author (2018).

2. Utilisation of the urban environment and people's behaviours (Table 4) based on observation notes, photographs and questionnaires. 
Table 4 - Evaluating the utilization of the urban environment and people's behaviours

\begin{tabular}{|c|c|c|c|c|c|c|}
\hline \multirow{3}{*}{$\begin{array}{c}\text { Visits } \\
\begin{array}{c}\text { Characteris- } \\
\text {-tics }\end{array} \\
\text { Cause of visit: }\end{array}$} & \multicolumn{6}{|c|}{ Evaluation of respondents' activities in the two public squares } \\
\hline & \multicolumn{3}{|c|}{ Harsous square HS activities (\%) } & \multicolumn{3}{|c|}{ May $1^{\text {st }} 1945$ square MS activities (\%) } \\
\hline & \begin{tabular}{|c|} 
Necessary \\
activities
\end{tabular} & $\begin{array}{l}\text { Optional } \\
\text { activities }\end{array}$ & $\begin{array}{l}\text { Resultant } \\
\text { activities }\end{array}$ & $\begin{array}{c}\text { Necessary } \\
\text { activities }\end{array}$ & $\begin{array}{l}\text { Optional } \\
\text { activities }\end{array}$ & $\begin{array}{l}\text { Resultant } \\
\text { activities }\end{array}$ \\
\hline & \multirow{2}{*}{\begin{tabular}{|c|} 
Walking to: \\
$\begin{array}{c}\text { Food shopping } \\
(55.6)\end{array}$
\end{tabular}} & \multirow{2}{*}{$\begin{array}{l}\frac{\text { Walking for }}{\text { HS to: }} \\
\text { Watching } \\
\text { around (23) }\end{array}$} & \multirow{2}{*}{$\begin{array}{c}\text { Greeting \& } \\
\text { chatting } \\
(65.2)\end{array}$} & \multirow{2}{*}{$\begin{array}{c}\text { Walking to } \\
\text { Food shopping } \\
(61.4)\end{array}$} & \multirow{2}{*}{$\begin{array}{l}\frac{\text { Walking to } M S}{\text { to: Watching }} \\
\text { around (17.8) }\end{array}$} & $\begin{array}{l}\text { Greeting and } \\
\text { chatting (35.7); }\end{array}$ \\
\hline & & & & & & $\begin{array}{c}\text { Weekend } \\
\text { selling: (10.4) }\end{array}$ \\
\hline & Work (17.3) & \multirow{3}{*}{$\begin{array}{c}\text { Go to the } \\
\text { post-office \& } \\
\text { banks (15.1) }\end{array}$} & \multirow{2}{*}{\begin{tabular}{|c} 
Play dominos \\
\& cards \\
$(22.4)$ \\
\end{tabular}} & \multirow[t]{2}{*}{ Work (18.5) } & \multirow{2}{*}{$\begin{array}{c}\text { Go to the } \\
\text { theater (11.3) }\end{array}$} & \\
\hline & School (9.2) & & & & & $\begin{array}{l}\text { Daily selling } \\
\text { (16.7) }\end{array}$ \\
\hline & \multirow{6}{*}{$\begin{array}{l}\text { Waiting for a } \\
\text { bus \& car } \\
\text { parking (17.9) }\end{array}$} & & \multirow[t]{6}{*}{ Selling (12.4); } & School (10.3) & \multirow[t]{2}{*}{ An event (16.9) } & \\
\hline & & \multirow{2}{*}{$\begin{array}{c}\text { Window } \\
\text { shopping } \\
(2.6)\end{array}$} & & \multirow{5}{*}{$\begin{array}{l}\text { Waiting for a } \\
\text { bus \& car } \\
\text { parking (9.8) }\end{array}$} & & Occasional \\
\hline & & & & & $\begin{array}{c}\text { Window } \\
\text { shopping }(26.6)\end{array}$ & selling (8.2) \\
\hline & & \multirow{2}{*}{$\begin{array}{c}\text { Sitting \& } \\
\text { resting at } \\
\text { café } \\
\text { terraces (43) }\end{array}$} & & & \multirow[t]{3}{*}{$\begin{array}{c}\text { Sitting \& resting } \\
(27.4)\end{array}$} & $\begin{array}{c}\text { Playing } \\
\text { Kharbga }^{8} \\
(21)\end{array}$ \\
\hline & & & & & & Children play \\
\hline & & $\begin{array}{c}\text { An event } \\
\text { (16.3) }\end{array}$ & & & & $\begin{array}{c}\text { around the } \\
\text { water-jet (8) }\end{array}$ \\
\hline \multirow[t]{2}{*}{$\begin{array}{l}\text { Time of visit: } \\
\text { (Peak hours) }\end{array}$} & $\begin{array}{c}\text { 7:30; 9:00; } \\
\text { 10:30; 12:00 } \\
\text { (AM) }\end{array}$ & $\begin{array}{l}\text { 9:00; 10:00; } \\
\text { (AM) }\end{array}$ & $\begin{array}{l}\text { 8:00; 9:30, } \\
11: 00 \text { (AM) }\end{array}$ & $\begin{array}{c}\text { 7:30; 9:00; 10:30; } \\
\text { 12:00 (AM) }\end{array}$ & $\begin{array}{l}\text { 9:00; 10:00; } \\
\text { 12:00(AM) }\end{array}$ & $\begin{array}{c}8: 00 ; 9: 30,11: 00 \\
\text { (AM) }\end{array}$ \\
\hline & $\begin{array}{c}1: 30 ; 4: 30,7: 00 \\
\text { (PM) }\end{array}$ & $\begin{array}{l}\text { 1:00; 4:30 } \\
\text { 6:00, 9:00; } \\
11: 30 \text { (PM) }\end{array}$ & $\begin{array}{c}\text { 3:30, 5:30, } \\
\text { 7:00, 8:30, } \\
\text { 10:30, } \\
12: 00(P M) \\
\end{array}$ & $\begin{array}{c}\text { 1:30; 3:30, 4:30 } \\
\text { 7:00 (PM) }\end{array}$ & $\begin{array}{c}\text { 1:00; 4:30, 6:00, } \\
\text { 7:30; 9:00; } 11: 30 \\
\text { (PM) }\end{array}$ & $\begin{array}{c}\text { 3:30, 5:30, 7:00 } \\
\text { 8:30, 10:30; } \\
\text { 12:00(PM) }\end{array}$ \\
\hline $\begin{array}{l}\text { Frequency } \\
\text { Per/day: }\end{array}$ & $\begin{array}{l}53.7 \geq 3 t / d a y \\
3 t / d a y \geq 46.3\end{array}$ & $\begin{array}{l}35.5 \geq 3 t / d a y \\
3 t / d a y \geq 64.5\end{array}$ & $\begin{array}{c}16.2 \geq 3 t / d a y \\
3 t / d a y \geq 83.3\end{array}$ & $\begin{array}{l}56.5 \geq 3 t / \text { day } \\
3 t / \text { day } \geq 43.5\end{array}$ & $\begin{array}{l}55.4 \geq 3 t / d a y \\
3 t / d a y \geq 44.6\end{array}$ & $\begin{array}{l}28.3 \geq 3 t / \text { day } \\
3 t / \text { day } \geq 71.7\end{array}$ \\
\hline Daily: & 53.3 & 24.6 & 32.6 & 59.6 & 54.3 & 29.3 \\
\hline Weekly & 22.7 & 54.8 & 26.9 & 24.7 & 29.7 & 34.2 \\
\hline Occasional & 24 & 20.6 & 40.5 & 15.7 & 16 & 36.5 \\
\hline \multirow[t]{2}{*}{ Stay duration: } & $2 \min \geq 74.3$ & $10 \min \geq 32.7$ & $1 \mathrm{~h} \geq 34.5$ & $2 \min \geq 54.2$ & $10 \min \geq 21.4$ & $1 h \geq 26.6$ \\
\hline & $10 \min \leq 25.7$ & $2 \mathrm{hrs} \leq 67.3$ & $3 \mathrm{hrs} \leq 65.5$ & $10 \min \leq 45.8$ & $2 \mathrm{hrs} \leq 78.6$ & 3hrs $\leq 73.4$ \\
\hline \multirow[t]{4}{*}{ Companion-ship: } & $\begin{array}{c}\text { With } \\
\text { neighbour } \\
(30.6)\end{array}$ & $\begin{array}{c}\text { With } \\
\text { neighbour } \\
(21.2) \\
\end{array}$ & $\begin{array}{c}\text { With } \\
\text { neighbour } \\
(30.9) \\
\end{array}$ & $\begin{array}{l}\text { With neighbour } \\
\text { (36) }\end{array}$ & $\begin{array}{l}\text { With neighbour } \\
\text { (27.2); }\end{array}$ & $\begin{array}{c}\text { With neighbour } \\
(22.6)\end{array}$ \\
\hline & $\begin{array}{c}\text { With friend } \\
(39.4)\end{array}$ & $\begin{array}{c}\text { With friend } \\
(56.4)\end{array}$ & friend (62.5) & With friend (29.5) & With friend (46.5) & With friend (56.6) \\
\hline & $\begin{array}{c}\text { with children } \\
\text { (6) }\end{array}$ & $\begin{array}{l}\text { With children } \\
\text { (9) }\end{array}$ & $\begin{array}{c}\text { with children } \\
\text { (3) }\end{array}$ & $\begin{array}{c}\text { with children } \\
\text { (11) }\end{array}$ & $\begin{array}{c}\text { With children } \\
\text { (20.1) }\end{array}$ & $\begin{array}{c}\text { with children } \\
\text { (15.4) }\end{array}$ \\
\hline & Alone (24) & Alone (13.4) & Alone (3.6) & Alone (23.5) & Alone (6.2) & Alone (5.4) \\
\hline \multirow[t]{3}{*}{$\begin{array}{l}\text { Variation of } \\
\text { activities: }\end{array}$} & $\begin{array}{c}\text { Waiting for } \\
\text { RDV, event } \\
\text { (46.3) }\end{array}$ & $\begin{array}{c}\text { Necessities } \\
\text { shopping } \\
(56.6) \\
\end{array}$ & $\begin{array}{c}\text { Shopping } \\
\text { (37) }\end{array}$ & $\begin{array}{l}\text { Waiting for RDV, } \\
\text { event (44.7) }\end{array}$ & $\begin{array}{c}\text { Necessities } \\
\text { shopping (58.3) }\end{array}$ & Shopping (36.8) \\
\hline & $\begin{array}{c}\text { Window } \\
\text { shoppings } \\
(21.2) \\
\end{array}$ & $\begin{array}{c}\text { Bus waiting \& } \\
\text { car parking } \\
(43.4)\end{array}$ & $\begin{array}{c}\text { Waiting for } \\
\text { RDV, event } \\
(41.5)\end{array}$ & $\begin{array}{c}\text { Window } \\
\text { shopping (22.5) }\end{array}$ & $\begin{array}{l}\text { Bus waiting \&car } \\
\text { parking (41.7) }\end{array}$ & $\begin{array}{c}\text { Waiting for RDV, } \\
\text { event (49.3) }\end{array}$ \\
\hline & $\begin{array}{c}\text { Resting \& } \\
\text { chatting (32.5) }\end{array}$ & 1 & $\begin{array}{c}\text { Bus waiting \& } \\
\text { car parking } \\
(21.5)\end{array}$ & $\begin{array}{c}\text { Resting \& } \\
\text { chatting (32.8) }\end{array}$ & I & $\begin{array}{c}\text { Bus waiting \& } \\
\text { car parking } \\
(13.9)\end{array}$ \\
\hline Gender mix: & $\begin{array}{l}\text { Yes } 9.3 \text { / } \\
\text { No } 90.7\end{array}$ & $\begin{array}{l}\text { Yes } 5.8 / \\
\text { No } 94.2 \\
\end{array}$ & $\begin{array}{l}\text { Yes } 3.2 \text { / } \\
\text { No } 96.8 \\
\end{array}$ & $\begin{array}{l}\text { Yes 10.1/ } \\
\text { No } 89.9\end{array}$ & $\begin{array}{l}\text { Yes 13.4/ } \\
\text { No } 86.6\end{array}$ & $\begin{array}{c}\text { Yes } 25.4 / \\
\text { No } 74.6\end{array}$ \\
\hline
\end{tabular}

Source: The author (2018).

\footnotetext{
${ }^{8}$ Kharbga in (Table 4) is an ancestral board game (strategy), well-known in northern Africa and generally played by groups of elderly people. For further details: Kharbga Game Network (2019).
} 
The criteria evaluated are related to social practices, perceptions according to cultural rites, habits with individual and collective representations within three categories of activity (necessary, optional and resultant). We evaluated the purposes of visits (going to the space or just passing through it), time (we targeted peak hours), visit frequency (daily: with 3 times/day as an average or occasional), stay duration ( 2 minutes as minimum, and 3 hours as maximum stay duration) depending on the type of activities we evaluated; also the variation visits and the "simultaneity" of activities.

Information also concerned users' characteristics (individual and collective, also interactions (coming to PSs with companions or alone; with children/family, friends, or being with strangers, i.e. possibilities and needs for new encounters), (in a mixed or non-mixed gender ambience) to assess the practice of segregation or integration; the urban sociability, the kinds of interaction and attachment to place that makes PSs attractive for their users.

Finally, incomplete questioners' surveys were not considered.

\section{Results and discussion}

The results from the survey enlightened us regarding the influence of the built environment and its features on the attractiveness of PSs. This attraction varies according to the data collected on sociodemographic variables, the components of the urban environment and functionalities with the utilization of the urban environment and people's behaviours. Nevertheless, the strong impact of cultural and political aspects on spatial perception, behaviour and representation, lead to the interpretation of the results and discussion detailed below. The data was calculated as percentage data and the questionnaire results were assessed using Excel.

Crosswise reading of the three tables is required for the discussion of the results.

The difference in the number of participants $\mathrm{N}=173$ in MS and N=97 in HS, is due to the dominant male appropriation in the use of HS, which did not facilitate my access as an investigating woman, unlike in MS where the users of the square are of mixed gender. Also, approaching men and women participants at the same time was much easier and more comfortable. This has been experienced in several in-situ investigations, especially in ethnographic approaches (Harfouche, 2019), where female researchers were obliged to act in a certain way or adapt numerous strategies to interact with male interviewees. There is also the aspect of not interrupting the current of daily life and holding the trajectory of the survey process (e.g., wearing a veil, observing and filming from a distant hidden point, pretending to be a journalist or a census agent, etc.) Thus, we discuss the results in five sections, starting with the spatial and physical aspects of the urban environment including accessibility, comfort and public facility management.

\section{Spatial accessibility, comfort and public facilities}

The survey demonstrated that the spatial accessibility of the two squares is constraining and unsafe for pedestrians and handicapped persons, particularly in terms of layouts, access and comfort. With a difference of $13.29 \%$ of effective accessibility for MS which benefits from more care to host events (because of its spatial openness and picturesque theatre facade) compared to $9.28 \%$ for HS which has a diurnal layout of café terraces (Table 3) for frequent activities and long lasting static resultant activities (65.5\% of stay durations last up to 3 hours), (Table 3 and Table 4 ) that complicates accessibility, since pedestrians must take a labyrinthine path. PSs corners and front sidewalks are used for chatting, standing in groups, watching, bargaining.

However good proximity, an easily localisable environment and walkability attenuate the difficult physical access to the squares. The concentration of all the activities and the proximity of public transport facilities, $97.94 \%$ for HS, and private cars, $55.50 \%$ for MS (endowed with busy roads and parking lanes) contribute to the attractiveness of these PSs with their necessary and optional activities (Table 3). 
The good quality of purchases and brands attract large numbers of people, as demonstrated by Koohsari et al. (2013) in their study on the importance of the proximity and perceptual qualities of the surrounding built environment, including street configuration, in the walkability of public spaces.

Inaccessibility also occurs through ineffective safety from traffic, due to the daily congested urban environment leading to unwalkable areas. The non-provision of good lighting and security systems is ineffective: $84.54 \%$ for HS and $55.49 \%$ in MS, making both squares insecure, especially at night (Table 3). "This generates coping mechanisms, avoidance behaviours, psychological defence" (Spielberger, 1972, p. 484), and develops a state of anxiety affecting users' habits, impacting visits and stay durations.

However, male users living in the neighbourhood of the PSs were not much bothered, even at night. They see that the squares are directly open to paths, the proximity of the theatre due to the lighting of its façade at night, and even the partially residential nature of the neighbourhood reduces mugging risks. This is proved by the difference in results between $44.51 \%$ for MS for effective safety versus $15.46 \%$ for HS (Table 3).

This feeling is not shared by female users who find that the emptiness of the place, the lack of the night lighting and the closed stores at 5 PM in winter, make the space useless, scary and that there is nothing left to do. This was pointed out by Blobaum \& Hunecke (2005) when talking about the difference in perceiving the same environment regarding the presence or absence of light.

Naceur (2004, p. 241) stated that the avoidance of female users' is the result of the layouts and management of the environments of the main squares. The proximity of the squares to the commercial areas traditionally and usually used by men (Moorish cafés, traditional groceries, stores and market, even motels) reinforces gender avoidance and impedes women's ease in space. What is discussed below as use segregation through practices is apparent in;

Its very open design, its lack of layout (bad seating, lack of reserved places, etc..); all these associated factors discourage any attempt to use this place by women. The quality of the space and the nature of the businesses carried out in it are two relevant factors in attracting female categories to an urban space.

\section{Weather condition and facility management}

Participants expressed dissatisfaction towards inefficient management of weather facilities: $62,89 \%$ for HS and 83.24\% for MS (Table 3). They adopt use strategies and visit and use the square depending on the weather in HS (e.g., taking sunbaths on winter days, avoiding sunlight and high temperature in summer, benefiting from breezy corridors at the end of summer days).

The difference in the results between the two squares is due to the fact that participants take shelter under the insufficient removable sun shading of café terraces which that shortens the duration of their stays of 3 hours for resultant activities in HS with 65,5\% comparing to 73,4\% in MS. Also, seating facilities remain insufficient: $75.25 \%$ for $\mathrm{HS}$ and $84 \%$ for MS, but acceptable due to the variety and simultaneity of activities (Table 3), with higher results of presence $74.3 \%$ for short stay durations of 2 minutes for necessary activities and $67.3 \%$ of stays for 2 hours for optional activities (e.g., shopping $56,6 \%$ and $46.3 \%$ for waiting for an appointment or an event, waiting for a bus or car parking activities $43.4 \%$ ). This is not the case in MS where the need to stay is more for optional activities with $78.6 \%$ for about 2 hours and $73.4 \%$ for resultant activities or for 3 hours for more varied activities (e.g., shopping, mostly food shopping and resting to have lunch: $58.3 \%$, waiting for appointments or events: $49,3 \%$, resting and chatting: $32.8 \%$ ), (Table 4). Participants complained about the lack of modern, aesthetic and maintained facilities with 77.32\% ineffectiveness for HS. Also, there is lack of vegetation and malfunctioning air cooling facilities, contrary to MS, where participants appreciate the shade of trees, lawns and the water-jet device, liked by the elder men, and the children's play area, but still insufficient with $83.24 \%$ ineffectiveness. Water remains a management matter, often the victim of unified design and poor management (Table 3). This leads us to discuss the aesthetic and landscape attributes of the urban environment. 


\section{Aesthetic conditions and landscape}

Participants considered that the urban environment's architecture and planning should be supported by the rehabilitation and restoration of ruined buildings, with 90,72\% ineffectiveness for HS, and lower at $79,19 \%$ for MS.

Most of young adults were attracted by the environmental amenities and lively ambiance of the crowded café terraces in HS, with $72.16 \%$ (Table 3) effectiveness, waiting for an appointment 46.3\%, meeting a friend $32.5 \%$ (Table 4 ).

Less crowded, but with varied frequent and long-lasting resultant activities, with practices concentrated in specific spaces, with 70,52\% of effectiveness MS is typically a forum for the elder men (playing kharbga, shopping and bargaining), (Table 4). The last part presents a discussion on the social aspects of PSs attractiveness including social accessibility and the different forms of interaction.

\section{Social accessibility with gender and age use disparities}

In (Table 2); We can clearly see the disparities of utilisation in the gender and age categories in the two PSs, with $92.7 \%$ of males and $7.22 \%$ of females passing by, particularly in HS, compared to an increase in female presence $34.10 \%$ for shopping or watching children playing.

But this is again dethroned by $65.90 \%$ of male occupation in MS (Tables 3). In HS, most of the mixed gender use, $9.3 \%$, occurs through necessary daily activities and does not last in time, with $74.3 \%$ of stays lasting less than 2 minutes, as opposed to $94.2 \%$ of male domination in optional and $96,8 \%$ in resultant activities, with $65.5 \%$ of stays lasting up to 3 hours (Table 4 ).

The uncomfortable layout of the terraces of the coffee shops in HS does not help to attract women or gender mixing. This represents a barrier to access and common sharing of PS, and has favoured gender occupation strategies in spaces, behaviour avoidance and male gathering dominance in both individual and collective activities, a point underlined by Goffman (1977) about gender affordances, dealing and compromises. Female are rarely present as individuals, especially for optional and resultant activities, where women are accompanied by a friend or a child; we saw an increase in gender mixing in this case.

The spatial openness of the square offers connectivity and visibility, which is a factor of safety from crime, a favourable condition for women's presence, specified by both (Blobaum \& Hunecke 2005; Van Eniss 2016).

In MS $10.1 \%$ of mixed necessary use and $13.4 \%$ in optional activities can be explained by the closeness of the market, services and bus stop, followed by $25.4 \%$ for the need to rest and have lunch with a mix of uses for resultant collective activities with long stay durations: $73.4 \%$ last for a duration of 3 hours. Contrary to HS, MS has an open layout configuration, with no barriers to accessibility (Table 4).

Regarding age disparity, MS is (called the elders' place) where the eldest retired men prefer to go for the evening kharbga game, shopping at the weekend pets market, and its proximity to the morning vegetable and meat market to idle, gather, play, and entertain in groups. Young adults respect this spatial domination by the elderly and avoid its special ambience, except to celebrate events. They prefer HS for its audience, terraces and proximity to other lively coffee clubs and shops in the adjacent neighbourhood called the "Benboualid alleys".

\section{Social interaction: individual and collective activities}

PSs in Algerian culture have long been men's places, linked to commercial exchanges. After the black decade, PSs have been invested less by women than men. They have long been considered as a space for doing nothing (idleness) and being futile, in parallel with all leisure practices. This affects women more and hinders anonymity; this could also be related to religious interpretations and old traditions. As Choay 
(1970) mentioned that we need to go back to the identification of the public space as a common collective space that reflects the "us" of society as a "whole". Being in such a space means having to pay attention to one's representation, not of oneself but of the larger family, the tribe, mainly the patriarchy which expresses a sense of common pride "Horma" that could be affected.

Secondly, resultant activities (e.g., leisure and resting) are considered as practices for men in public spaces (Table 4) that have acquired through time a strict separation between men and women Navez-Bouchanine (2005). This was also the case in most societies before the 19th century.

The assumption that women properly 'belong' in or near the dwelling, whereas men may have easy and frequent access to places distant from the dwelling, where a larger number of people gather, is characteristic of most societies throughout the world. (Franck \& Paxson 1989, p. 123).

Thus, historically the old version of coffee-clubs or coffee-shops was "Moorish cafés", where in most Maghreb and Arab countries, these are places for males (mainly the eldest ones) to gather and rest, discuss political and social ideas and issues; while private women's spaces (houses) and then (covered markets) replaced them for necessary, optional and resultant activities. Nowadays, women's presence in PSs has more or less gained acceptance in practices and in spatial occupation, though segregation is still latent in leisure activities that arise due to a complex social order that defines spatial occupation.

Here, we are looking at a typical PS where cultural codes, management policies and rules of use change its canonical character of common public space, somehow different from its counterparts elsewhere in the world regarding the practices and behaviours of its users. The PS remains an example of ceaseless change. The PS remains a place of interaction, for individual and collective representation and being with other "strangers", in several complex processes that redefine people's presence in it and thus our right and access to the city.

Examining the interaction between people and places, considering the functional dimension of attachment, could provide more profound understanding of the relationship between the physical, social and psychological components of a place.

\section{Conclusion}

This study proved that public spaces are important and essential elements for the urban life and the vitality and promotion of the city. The public squares studied offer important opportunities for residents of Batna in their daily activities and practices to reintegrate and create a common civic life in a spontaneous way. Nevertheless, the cultural, political and economic issues associated with urban management policies have little impact on the development and perception of public spaces and their use. The components of the urban environment and its functionalities provided acceptable facilities for people to use, especially in terms of proximity; but the lack of effective infrastructures, aesthetic treatment, traffic safety and comfort, with outmoded features accentuated by unsatisfactory management, have decreased users' accessibility which affects the attractiveness of these public spaces. However, they could be reconquered by varying activities, by simultaneity and by duration. Participants talked at length about their need to be there, not just for shopping, but to relax, see people, and exchange and share moments, in discussion or play.

People come to PSs for necessary and frequent optional activities, and they stay for resultant ones (varied long-lasting activities such as playing, chatting or watching sports broadcasts for men in evenings) or just passing (unvaried necessary or resultant transient activities for women). They are mostly visited in summer during the heat, festivities and Ramadan evenings (whose nocturnal ambience allows invisibility and anonymity, and thus tolerance to gender coexistence).

It is clear that social attraction resides in a safe, comfortable and aesthetically attractive environment, which is what is sought in common spaces, with variated individual and collective activities with a mix of age and gender use. These encourage socialization in a practical, common urban environment, thus achieving the successful enhancement and revitalization of lively public spaces in the city of Batna. 


\section{References}

Abu-Dayyeh, N. (2018). Public urban space: the linguistic turn. Cogent Arts \& Humanities, 5(1), 1523515. http://dx.doi.org/10.1080/23311983.2018.1523515.

Anderson, J., Ruggeri, K., Steemers, K., \& Huppert, F. (2017). Lively social space, well-being activity, and urban design: findings from a low-cost community-led public space intervention. Environment and Behavior, 49(6), 685716. http://dx.doi.org/10.1177/0013916516659108.

Barnett, E., \& Casper, M. (2001). A definition of 'social environment'. American Journal of Public Health, 91(3), 465. http://dx.doi.org/10.2105/AJPH.91.3.465a. PMid:11249033.

Blobaum, A., \& Hunecke, M. (2005). Perceived danger in urban public space: the impacts of physical features and personal factors. Environment and Behavior, 37(4), 465-486. http://dx.doi.org/10.1177/0013916504269643.

Carmona, M. (2015). Re-theorising contemporary public space: a new narrative and a new normative. Journal of Urbanism, 8(4), 373-405. http://dx.doi.org/10.1080/17549175.2014.909518.

Carmona, M., Heath, T., Oc, T., \& Tiesdell, S. (2003). Public places, urban spaces: the dimensions of urban design. Oxford: Architectural Press.

Carmona, M., Magalhães, C., \& Hammond, L. (2008). Public space: the management dimension (1st ed., pp. 10). New York: Routledge Press.

Cooper Marcus, C., \& Francis, C. (Eds.). (1998). People places: design guide- lines for urban open spaces (2nd ed.). New York: Van Nostrand Reinhold Publishers.

Cote, M. (1991). Batna. In G. Camps (Ed.), Encyclopédie Berbère: Baal - Ben Yasla (Vol. 9, pp. 1389-1394). Aix-enProvence: Edisud.

Childs, M. C. (2004). Squares: a public place design guide for urbanists. Albuquerque: University of New Mexico Press.

Choay, F. (1970). La règle et le modèle, sur la théorie de l'architecture et l'urbanisme. Paris: Éditions du Seuil.

Davis, M. (1992). City of Quartz. New York: Vantage.

Delcampe International. (2019). Retrieved in 2019, January 1, from www.delcampe.net

Francis, J., Giles-Corti, B., Wood, L., \& Knuiman, M. (2012). Creating sense of community: the role of public space. Journal of Environmental Psychology, 32(4), 401-409. http://dx.doi.org/10.1016/j.jenvp.2012.07.002.

Franck, K. A., \& Paxson, L. (1989). Women and urban public space: research, design and policy issues. In I. Altman, \& E. Zube (Eds.), Public spaces and places (pp. 121-146). New York: Plenum. http://dx.doi.org/10.1007/978-14684-5601-1_6.

Gehl, J. (1996). Life between buildings: using public space (3rd ed.). Copenhagen: Arkitektens Forlag.

Gehl, J. (2004). Public spaces, public life. Copenhagen: The Danish Architectural Press.

Goffman, E. (1977). The arrangement between the sexes. Theory and Society, 4(3), 301-331.

http://dx.doi.org/10.1007/BF00206983.

Guedoudj, W. (2013). Étude analytique des espaces publics urbains en Algérie: cas des places et placettes de la ville de Batna (Magister thesis). University of Biskra, Algeria.

Hafiane, A. (2007). Les projets d'urbanisme récents en Algérie. In 43rd ISOCARP Congress. Hague: International Society of City and Regional Planners.

Harfouche, A. (2019). Les femmes et l'espace public en Algérie: appropriation et sociabilités publiques à Sétif (Doctorate thesis). University of Paris Nanterre, France.

Harnik, P. (2003). The excellence city park system: what makes it great and how to get there. Washington: The Trust for Public Land Pub. 
Hines, S. (2001). Online American Society of Landscape Architects Newsletter.

Kharbga Game Network. (2019). Retrieved in 2019, January 1, from http://kharbga.net/kharbga/

Koohsari, M. J., Karakiewicz, J. A., \& Kaczynski, A. T. (2013). Public open space and walking: the role of proximity, perceptual qualities of the surrounding built environment, and street configuration. Environment and Behavior, 45(6), 706-736. http://dx.doi.org/10.1177/0013916512440876.

Latour, B. (2005). Reassembling the social: an introduction to actor-network-theory. Oxford: Oxford University Press.

Low, S., Taplin, D., \& Scheld, D. (2005). Rethinking urban parks: public space \& cultural diversity. Austin: University of Texas Press.

Marans, R. W. (2012). Quality of urban life studies: an overview and implications for environment-behaviour research. Procedia: Social and Behavioral Sciences, 35, 9-22. http://dx.doi.org/10.1016/j.sbspro.2012.02.058.

Marin, J-P. (2005). Au forgeron de Batna (Collection Graveurs de Mémoire). Paris: Editions L'Harmattan.

Mehta, V. (2007). Lively streets: determining environmental characteristics to sup- port social behavior. Journal of Planning Education and Research, 27(2), 165-187. http://dx.doi.org/10.1177/0739456X07307947.

Mehta, V. (2013). The street: a quintessential social public space. New York: Routledge. http://dx.doi.org/10.4324/9780203067635.

Mele, C., Ng, M., \& Chim, B. (2015). Urban markets as a 'corrective' to advanced urbanism: the social space of wet markets in contemporary Singapore. Urban Studies, 52(1), 103-120.

http://dx.doi.org/10.1177/0042098014524613.

Morgan, D. (2009). Acquaintances: the space between intimates and strangers (p. 2). Maidenhead: Open University Press.

Naceur, F. (2004). La problématique de la dominance masculine au niveau des espaces urbains: cas des villes algériennes. In S. Denèfle (Ed.), Femmes et villes (pp. 239-248). Tours, France: Presses Universitaires FrançoisRabelais.

Naceur, F. (2007). Les jardins publics à Biskra: d'un espace de rencontre élitaire à une zone de non droit. In M. Berlan-Darqué, Y. Luginbühl, \& D. Terrasson (Eds.), Paysages: de la connaissance à l'action (pp. 115-122). Versailles: Éditions Quæ.

Naceur, F. (2017). Des femmes dans l'espace public: places et jardins à Batna. Les Annales de la Recherche Urbaine, 112(1), 106-115. http://dx.doi.org/10.3406/aru.2017.3244.

Navez-Bouchanine, F. (2005). Les espaces publics des villes maghrébines, enjeu et partie prenante de l'urbanisation. In J.-L. Arnaud (Ed.), L'urbain dans le monde musulman de Méditerranée (pp. 101-119). Rabat: Institut de Recherche sur le Maghreb Contemporain. http://dx.doi.org/10.4000/books.irmc.296.

Pacheco, P. (2017, June 9). Public spaces: 10 principles for connecting people and the streets. The City Fix. Retrieved in 2019, January 1, from https://thecityfix.com/blog/public-spaces-10-principles-for-connecting-people-and-thestreets-priscila-pacheco/

Projet for Public Space. (2000). What makes a successful place? New York: Project for Public Spaces Inc. Retrieved in 2019, January 1, from https://www.pps.org/article/grplacefeat

Rahal, M. (2017). 1988-1992: multipartism, Islamism and the descent into civil war. In P. Crowley (Ed.), Algeria: nation, culture and transnationalism: 1988-2013. Oxford: Oxford University Press.

http://dx.doi.org/10.5949/liverpool/9781786940216.003.0005.

Rapport, N. (1999). The 'bones' of friendship: playing dominoes with Arthur of an evening in the Eagle Pub. In S. Bell, \& S. Coleman (Eds.), The anthropology of friendship (pp. 99-117). Oxford: Berg. 
Richaud, L. (2018). Between 'face' and 'faceless' relationships in China's public places: ludic encounters and activity-oriented friendships among middle- and old-aged urbanites in Beijing public parks. Urban Studies Journal, 1(18), 570-588. http://dx.doi.org/10.1177/0042098016633609.

Spielberger, C. D. (1972). Conceptual and methodological issues in anxiety research. In C. D. Spielberger (Ed.), Anxiety: current trends in theory and research (Vol. 2, pp. 481-493). New York: Academic Press. http://dx.doi.org/10.1016/B978-0-12-657402-9.50013-2.

Steinmuller, H. (2011). The moving boundaries of social heat: gambling in rural China. Journal of the Royal Anthropological Institute, 17(2), 263-280. http://dx.doi.org/10.1111/j.1467-9655.2011.01679.x.

Tanaka, F., \& Kikata, J. (2008). Research on urban landscape and public space by the caption evaluation method: case study on Kagoshima city. Architectural Institute of Japan Research Paper, 47(3), 221-224.

Ujang, N. (2014). Place meaning and significance of the traditional shopping district in the city Centre of Kuala Lumpur, Malaysia. Archnet-IJAR: International Journal of Architectural Research, 8(1), 66-77. http://dx.doi.org/10.26687/archnet-ijar.v8i1.338.

Ujang, N., Kozlowski, M., \& Maulan, S. (2018). Linking place attachment and social interaction: towards meaningful public places. Journal of Place Management and Development, 11(1), 115-129. http://dx.doi.org/10.1108/JPMD01-2017-0012.

Van Eniss, N. (2016). La place des femmes dans l'espace public, seulement une question d'aménagment du territoire. Liège: Barricade Culture d'Alternative. Retrieved in 2019, January 1, from http://www.barricade.be

Whyte, H. W. (1980). The social life of small urban spaces. Washington: Conservation Foundation.

Whyte, H. W. (2000). How to turn a place around. New York: Project for Public Spaces Inc.

Editor: Rodrigo Firmino

Received: Jul. 08, 2019

Approved: Jan. 27, 2020 